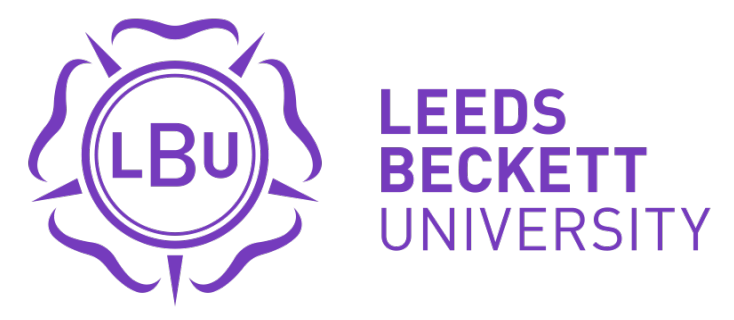

Citation:

Uddin, M and Chowdhury, A and Zafar, S and Shafique, S and Liu, J (2018) Institutional determinants of inward FDI: Evidence from Pakistan. International Business Review. ISSN 0969-5931 DOI: https://doi.org/10.1016/j.ibusrev.2018.10.006

Link to Leeds Beckett Repository record:

https://eprints.leedsbeckett.ac.uk/id/eprint/5428/

Document Version:

Article (Accepted Version)

The aim of the Leeds Beckett Repository is to provide open access to our research, as required by funder policies and permitted by publishers and copyright law.

The Leeds Beckett repository holds a wide range of publications, each of which has been checked for copyright and the relevant embargo period has been applied by the Research Services team.

We operate on a standard take-down policy. If you are the author or publisher of an output and you would like it removed from the repository, please contact us and we will investigate on a case-by-case basis.

Each thesis in the repository has been cleared where necessary by the author for third party copyright. If you would like a thesis to be removed from the repository or believe there is an issue with copyright, please contact us on openaccess@leedsbeckett.ac.uk and we will investigate on a case-by-case basis. 


\title{
Institutional Determinants of Inward FDI: Evidence from Pakistan
}

\author{
Moshfique Uddin \\ Anup Chowdhury \\ Sheeba Zafar \\ Sujana Shafique \\ Jia Liu
}

(Accepted for Publicaiton in IBR on 9 October 2018)

\section{Introduction}

Since the mid-1990s, the global growth of inward and outward FDI flows has been remarkable (Villaverde and Maza, 2015). FDI flows to emerging countries have also increased substantially over the same period of time (Xiao and Park, 2018). The concomitant benefits of FDI, ranging from the ingress of technological knowledge and management skills, to non-obligatory capital flows and increased employment and production capacity, have stimulated this spectacular progress of global FDI (Oxelheim and Ghauri, 2008). This buoyant global phenomenon has given rise to increasing academic research into the determinants of FDI, both inward and outward, inspiring much academic debate over the last two decades. Investigations into the determination of FDI flows have so far offered better explanations of outward than of inward flows.

Dunning's eclectic theory (1980 and 2000), also known as Ownership, Location, and Internationalization (OLI) paradigm, offers a comprehensive explanation of FDI activities that incorporates ownership, location and the internalization advantages of foreign investment as significant stimulants of inward FDI flows. Location advantages specific to a host country render it more attractive for FDI than competing countries. However, Kang and Jiang (2012) contend that the OLI paradigm places more emphasis on economic efficiency and less on institutional legitimacy, which is a crucial consideration for MNCs when they make decisions on direct investments in foreign countries. Similarly, Pajunen (2008) asserts that the OLI paradigm can only partially explain locational advantage, recognising the need to consider institutional factors when 
assessing the attractiveness of a country as a destination for foreign investment. Even Dunning (2006) adds his support to the argument that institutional factors are important when analysing the FDI decision.

Given the foregoing observations, it is clear that institutional theory has grown in importance in exploring the FDI phenomenon, and has a particular relevance to the study of emerging economies (Hoskisson et al., 2000). However, thus far there is a paucity of research linking institutional factors and FDI in emerging markets (Bailey, 2018). To address this dearth, our study will examine the institutional determinants of FDI inflows of an emerging market. Within this framework, we consider institutions as a set of social, political and economic elements, as defined by North (1990), and examine how institutions shape the inward FDI decision of foreign investors. These institutional elements are of paramount importance for foreign companies making direct investments across borders because they collectively influence the success of companies engaging in FDI (Scott, 2014).

We base our investigations of the institutional determinants of inward FDI on Pakistan, where the problematical nature of the institutional structure makes it a suitable proxy for other emerging or developing markets, where similar institutional and regulatory problems are often found, thus creating a template for regulatory policy and practice. Since gaining independence in 1947, the institutional environment in Pakistan has remained weak. The country has suffered from perennial political instability, high levels of corruption, feeble enforcement of law and order and ineffective governance for a protracted period (Shah et al., 2016). Although, since 1988, the government has initiated a series of liberalization programmes to attract FDI, these have failed to achieve their objectives (Khan, 1997). The recent flow of foreign investment to Pakistan has decreased significantly (Tahir et al., 2015), with inflows declining acutely since 2011. Haq and Zia (2009) suggest that this is because of weak institutions. Although several studies have examined Pakistan's FDI inflows (e.g., Azam and Khattak (2009); Hakro and Ghumro, 2011; Hunjra et al. (2013), the 
majority of those have concentrated on general macroeconomic determinants. Focusing solely on macroeconomic factors represents a suboptimal solution to the investigation of FDI determinants, as macroeconomic conditions are shaped by institutional factors. A weak institutional system can reduce cooperation within factor markets and undermine economic restructuring by causing under employment, market segmentation and technological exclusion (Caballero and Hammour, 2001). Accordingly, we must examine institutional determinants of FDI in addition to macroeconomic factors to help policy makers create an environment supportive of FDI. We note that Shah et al. (2016) have applied institutional theory to FDI in Pakistan. However, their study uses a single, composite index of institutions rather than looking at their intrinsic components.

Our study differs from previous investigations in several ways. First, we incorporate a wider range of institutional elements to cover social, political and economic institutions, deriving a comprehensive model. As Trevino et al. (2008) argue, most studies have predominantly examined the influence of market and regulatory institutions, discounting other institutional components, even though these have been shown to influence the foreign investment decision (Pajunen, 2008). In contrast, our study is based on an examination of integrated institutions, and its findings will help policy makers to identify the institutional components that have the greatest impact on FDI. Second, we examine the structural break to see if institutional reform in Pakistan, undertaken in the early 1990s, has helped to enhance FDI. Third, Pakistan has been afflicted by a volatile political situation, continually alternating between democratic and military government, since independence. In our study, we examine this important institutional phenomenon and evaluate how it has affected FDI inflows during this period. Finally, our study considers the elasticity of each institutional factor and assesses its relative importance in determining inward FDI, enabling policy makers to focus their endeavours on the most significant determinants of growth.

Our study derives several important findings. First, institutional factors significantly influence FDI in Pakistan. The effect becomes more pronounced during the post liberalisation period compared 
to before, confirming the benefit of market liberalisation during the early 1990s. Another notable finding is the positive effect of military governments in attracting foreign investment compared to democratic governments. Third, our elasticity tests demonstrate that labour cost, regulations governing credit market, labour market and business are the most important institutional factors influencing FDI inflows.

The remainder of this paper is organised as follows. Section two provides a brief overview of FDI in Pakistan. Section three discusses the literature and addresses the main institutional factors considered by our study. Section four discusses data and methods. Section five presents the results and discussions. Section six details our conclusions and policy implications.

\section{Brief overview of FDI in Pakistan}

The general economic outlook of Pakistan ${ }^{1}$ is favourable to become a natural destination of foreign investment. For example, Pakistan is the sixth most populous country in the world and placed at $41^{\text {st }}$ position in terms of projected GDP in 2018 as reported by International Monetary Fund (IMF) $)^{2}$. KPMG (2017) reported that Pakistan has been successful in attaining smoother growth rate of around $5 \%$ for the last five years and has a large labour force $\left(8^{\text {th }}\right.$ largest in the world) to support this upsurge in growth. Wage levels are comparatively lower (ILO) and there are abundant natural resources. Baldwin (2016) argues that in an age of globalisation, capital is flowing to countries with low labour costs and a higher growth potential. Therefore, with an availability of cheap labour and a higher growth rate than developed countries, Pakistan ought to have been successful in attracting FDI. Moreover, KPMG (2017) reported that Pakistan has one of the most liberal foreign investment regimes in South Asia with an opportunity of $100 \%$ foreign equity investment in almost all sectors and a fast growing private sector to support foreign investment. However, inward investment has not been as good as might have been expected. We present FDI

\footnotetext{
${ }^{1}$ Pakistan is classified as an emerging market by the International Monetary Fund.

${ }^{2}$ International Monetary Fund - World Economic Outlook 2018
} 
inflows in Tables 1,2 and 3. Table 1 shows the relative FDI inflow compared to developed and developing markets (including other emerging markets) for various periods from 1970, from which it is clear that Pakistan has failed to attract a satisfactory level of FDI compared to China and India. For example, in 2012, when emerging markets received more than a fifty percent share of FDI inflow globally, Pakistan secured only 0.063 percent of the total, significantly less than emerging markets such as China (8.96\%) and India (1.89\%).

\section{Insert Table 1 here.}

Tables 2 and 3 show the country and sector-wise FDI inflow (\% of GDP) in Pakistan, respectively, between 2008 and 2016. During this period, foreign investment decreased from 2.18 percent to 0.85 percent of GDP. Surprisingly, most of the investment was from conventional investors, such as the US, UK and UAE. This suggests that Pakistan has been unable to attract investment from new countries. Table 3 shows the sectoral distribution of FDI from 2008 to 2016. Data from sectoral distribution also provides evidence of poor performance and slow growth in attracting FDI. This poor performance can be attributed to various institutional factors. Shah et al. (2016) report that Pakistan is positioned lower than one hundredth place in several institutional indexes, including law and order, government stability, corruption, democratic accountability, and bureaucratic quality. Given such a context, it is important to examine if, and how, these and other institutional elements have influenced FDI inflows. Moreover, it is even more important to identify which of these institutional variables have had the greatest impact on FDI. Examining these factors is of critical importance, since the recent financial crisis has made emerging economies more vulnerable, due to their weak and fragile institutional structures (Gevorkyan and Canuto, 2016).

Insert Table 2 and 3 here.

\section{Literature review}

A nation's institutional framework comprises political, economic and social elements (North 1990; 1998; Scott, 1995). These elements form the basis of exchange and production (Sobel, 2002). 
North (1990) and Khanna and Rivkin (2001) argue that social, political and economic institutions affect the profitability of a firm in a particular country by influencing transaction and transformation costs. Therefore, the characteristics of a country's institutions are important factors in attracting foreign investment (Dunning, 2006). Similarly, Delios and Henisz (2000) suggest that a country's institutional setting influences an MNC's decision to invest. Ghemawat (2001) argues that a foreign country can become an attractive investment destination if the distance between host and home country is not great. Applying the CAGE framework, Ghemawat (2001) identifies four kinds of distance: cultural, administrative, geographic and economic, arguing that weaker institutions in the host country may increase the perceived distance between the latter and the home country and therefore depress foreign investment. Institutional integrity plays a more important role than explicit trade restrictions and so should be enhanced to make a country more attractive as an investment location (Ghemawat, 2001). Similarly, Arregle et al. (2016) note that country level institutional approaches facilitated understanding of the location pattern of internationalisation. Emphasising the great importance of institutional factors in explaining the FDI location decision, Dunning (2006) proposes that future research should consider institutional factors as well as the traditional factors proposed in his own OLI theory.

The institutional environment in emerging markets is different from that in developed markets. Khanna and Palepu (2005) identify the absence or under-developed nature of important institutional elements in emerging markets. MNCs therefore need to take care when investing in emerging markets as institutional weaknesses create more uncertainty, higher business risks and increased transaction costs (Rottig, 2016). Kostova and Zaheer (1999) and Scott (2014) stress that MNCs must cautiously evaluate institutional factors when selecting an investment location, as this is crucial in determining success. Several studies have determined that better institutional quality in a host country attracts FDI, as superior institutions reduce investment risk by facilitating the process of doing business (Nielsen et al., 2017; Bevan et al., 2004 and Sethi et al., 2003). Bailey (2018) argues that institutional factors, such as democratic institutions, political stability, rule of 
law, corruption, tax policies and culture are important factors influencing FDI. He further argues that institutional factors are more influential in attracting FDI in emerging countries compared to developed countries, and the effect of institutional factors is stronger in emerging countries in Asia compared to those in North America and Europe. In this study, we have identified and examined several institutional factors that potentially influence the FDI inflows.

\subsection{Size of Government}

The size of government influences FDI inflow by enhancing its ability to regulate economic growth and increase the effectiveness of its public policies. Newton (1982) and Garcia-Sanchez et al. (2013) argue that larger government can reflect government effectiveness by providing numerous socially desirable services. Pajunen (2008) points out that the FDI decision is predominantly influenced by the attractiveness of the host country's economic growth. Government can influence this by providing public goods (Holmes Jr. et al., 2013), building infrastructure (Yuan et al., 2010), controlling corruption (Buchanan et al., 2012), providing a sound regulatory environment (Globerman and Shapiro, 2002), and ensuring good governance (Globerman and Shapior, 2003). Increased size of government, as reflected by increased taxation and investment, a higher level of consumption and transfer payments, helps to promote economic growth through redistribution of wealth, encouraging foreign investment (Yuan et al. 2010). The positive effect of government size on inward FDI may be even more significant in emerging countries, where the marginal benefit of government spending is much higher in attracting foreign investment by stimulating economic growth. For example, Asimakopoulos and Karsvias (2016) find that the majority of emerging and developing countries are still at the upward sloping segment of BARS curve, indicating that such countries benefit more from higher government investment and expenditure.

\subsection{Property rights and the regulatory framework}

Property rights and regulations are the two most important elements influencing the host country's 
choice of Global Multinational Enterprises (MNEs) (Bailey, 2018; Choi et al., 2016; Tanaka and Iwaisako, 2014; Holmes et al., 2013; Asiedu and Lien, 2011; Pajunen, 2008; Globerman and Shapiro, 2003; Li and Resnick, 2003). Dunning (1981), applying his OLI framework, postulates that property rights and the regulatory environment are two important components affecting the decision of MNEs to produce internationally. He further argues that efficient institutions reduce transaction costs, which may arise due to inadequately protected property rights and the absence of a properly regulated institutional system. Additionally, a strong regulatory framework reduces uncertainty, protecting MNEs and permitting foreign competition by addressing market failure, which should increase efficiency and improve profitability (Bailey, 2018; Li and Resnic, 2003). Choi et al. (2016) further suggest that the effective rule of law, allied to a stable institutional environment, are necessary conditions for a firm to initiate or maintain business. Rammal and Zurbruegg (2006) show that a deterioration in the enforcement of investment regulations adversely affects FDI. Examining five Asian countries, they find this to be a significant cause of a reduction in FDI. Pajunen (2008) argues that support of labour regulations, a sound judicial system, an effective rule of law and general justice are important institutional factors encouraging FDI flows.

\subsection{Democracy and political stability}

Pajunen (2008) argues that the political regime and political risk are important institutional factors conducive to attracting FDI. Similarly, using data from emerging markets, Holmes Jr. et al. (2013), Ahlquist (2006), Asiedu (2006), Globerman and Shapiro (2002) find evidence to support political stability as a determinant of FDI. Holmes Jr. et al. (2013) argue that democratic rather than autocratic government is more favourable in attracting FDI. Democracy affords managers of MNEs the opportunity to influence the system in their favour through interest groups, elections and lobbying. Conversely, autocratic government may be seen as a source of instability and unpredictability, with power confined to a small number of people. Studying ninety developing countries, Ahlquist (2006) finds that with a more stable government regime and democratic 
political institutions, a country can attract more FDI, particularly from direct investors, who are more sensitive to political considerations. However, democracy may create obstacles to favourable policy changes because of higher numbers of veto players (Henisz, 2000). Olson (1991) argues that autocracy facilitates the implementation of property rights by promoting long-run stability in a country, hence attracting foreign investors. Similarly, Asiedu and Lien (2011) mentioned that autocracy provides stability of economic policies as opposed to democracy which involves a frequent changes in government officials. Economic Intelligence Unit report (EIU, 2008) has also confirmed that autocratic government is more conducive to stable and predictable business environment. Haggard (1990) and Greider (1998) argue that FDI favours autocracy because this suppresses labour demands, represses protesters and offers tax incentives to MNCs to encourage FDI. Li and Resnick (2003) provide supportive evidence for autocracy as a facilitator of FDI, which they assert helps MNCs to maintain their monopolistic position in the host market. Asiedu and Lien (2011), Busse (2004) and Gani and Al-Abri (2013) also find that autocracy helps to attract FDI in host countries. Conversely, democracy can create the threat of terrorism in lower income countries (Chenoweth, 2013), which may discourage FDI by causing political instability and increasing the cost of doing business (MengYun et al., 2018).

\subsection{Economic policy and market openness}

Theory suggests that the positive effect of economic policies and market openness or liberalisation can favourably influence FDI. Ahlquist (2006) examines the effect of economic policy outcomes on cross-country capital movements, finding that portfolio investors are sensitive to past government behaviour and fiscal policy outcomes. Holmes Jr. et al. (2013) provide evidence of the strong influence of economic institutions on FDI in a study of fifty countries. They emphasise the role of monetary and fiscal policies and financial market development in attracting FDI. Market openness or liberalisation, both trade and financial, are also regarded as important determinants in attracting FDI. Okada (2013) finds that the interaction effects of financial openness and 
institutional quality have a positive influence on capital inflows. Reinhardt et al. (2013) demonstrate that financially open, less developed economies tend to experience net capital inflow. Aizenman and Noy (2006) report a strong feedback effect between trade and FDI in developing countries. Similarly, Kim et al. (2013), Medvedev (2012) and Büthe and Minler (2008) further emphasise the positive impact of trade liberalisation on FDI inflow.

\subsection{Political rights and civil rights}

The strength of an individual's political rights and civil liberties favours the development of human capital, increasing the efficiency of FDI inflows (Dutta and Osei-Yeboah, 2013). The latter argue that domestic human capital is a strong determinant of foreign direct investment inflows for the developing world; yet the contribution of human capital will depend to a great extent on the institutional framework of a nation. Political and civil rights are also significant to MNCs' investment decisions. Adam and Filippaios (2007) distinguish between civil and political liberties and assert that MNCs tend to invest in countries with strong political liberties. A threshold level exists for civil rights, below which repression of civil liberties is associated with greater FDI. Busse (2004) also finds that countries with improving rights and liberties receive more FDI per capita than would have been predicted on the basis of other country characteristics. An affirmative association between these factors is reported in Filippaios et al. (2017), Blanton and Blanton (2006), Harms and Ursprung (2002). In their recent work, Filippaios et al. (2017) test the hypothesis on a sample of 35,000 investment projects in 110 developing and emerging economies, finding a linear relationship between civil liberties and FDI.

Given the foregoing discussion, we propose that a multinational's decision on location is governed more by an integrated institutional environment than by individual factors. Our study explores the role of a range of institutional factors that are expected to determine inward FDI in Pakistan. More specifically, our investigation incorporates the size of government, property rights, legal systems, access to sound money, freedom of international trade, political and civil rights, the nature of the 
government regime and democracy as influential institutional factors that may influence inward FDI flows to Pakistan.

\section{Methodological issues}

\subsection{Institutional quality variable construction ${ }^{3}$}

The first variable for measuring institutional quality is derived from the Economic Freedom of the World-index (EFW), which is widely used and jointly published by the Fraser and The Cato Institutes. The EFW is one of the most comprehensive sets of indicators measuring economic freedom and institutional quality over the longest time span. The most recent edition includes five components constructed from 42 subcomponents available for 150 countries. The index comprises five un-weighted average components, reproduced for a country's institutional quality with respect to: (i) Size of Government: Expenditures, Taxes, and Enterprises (SGOV); (ii) Legal Structure and Security of Property Rights (PROR); (iii) Access to Sound Money (SMON); (iv) Freedom to International Trade (FTRAD); and (v) Regulations of the Credit market, Labour market, and Business (REGUL). The Fraser Institute uses a 0 to 10 scale for each category, calculating an average of these five indices to derive an overall index. In this index, zero represents the lowest quality of economic institutions and 10 represents the highest level of institutional quality. The data of the EFW index is available for every five years from 1970 to 1999 and subsequently annually. Our sample begins in 1972 and, hence, we use the given values as the average between available samples to fill in the missing observations until 1999.

Secondary measures that we use in our model are Political Rights (PR) and Civil Liberties (CL), as recommended in Khan (2011), Mhlanga et al. (2010), Busse (2004), and Harms and Ursprung (2002) and are taken from Freedom House. Freedom House has published annually comparative evaluations of civil liberties and political rights for 14 related and disputed territories and 195

\footnotetext{
${ }^{3}$ We present a detailed list of factors in Appendix along with the reference to studies that have incorporated those variables in their studies when investigating their associations with FDI inflow.
} 
countries since 1972. They allocate two numerical ratings for each category, based on a scale of 1 to 7 for each country and territory. Harms and Ursprung (2002) and Mhlanga et al. (2010) use these variables to measure the institutional environment and political instability by taking the sum of civil liberties and political rights divided by two $[(C L+P R / 2)]$. In our study, we use PR and CL separately to examine their individual impact on inward FDI.

Our third factor is Polity-IV ${ }^{4}$ (POLIIV) for measuring democratic governance. Recent theoretical and empirical studies (such as Jensen, 2003; Li and Resnick, 2003; Jakobsen and Soysa, 2006) suggest that, beyond its contribution to property rights, democracy has a notably ambiguous effect on FDI inflows. They use Polity-IV (Polity-III in Jensen, 2003) to measure the democracy of the host country.

Finally, we use average labour cost (LCOST) as a control variable, as suggested in Bellak et al. (2008), Johnson (2006), Bevan et al. (2004) among others (see Table 1, Bellak et al. (2008) for a detailed list of papers that use labour cost). The importance of including labour cost is further highlighted in Fontagne and Mayer (2005) who argue that both market-related and cost-related factors should be included in an empirical study of FDI flows.

\subsection{Data and sample}

The FDI data for Pakistan is collected from Datastream and updated from various national and official sources, such as the Handbook of Statistics published by the State Bank of Pakistan (SBP) and the Board of Investment of Pakistan. Since quarterly data are not available for all the economic variables, we have used annual data from 1972-2016, which provides quarterly data. The unavailability of quarterly data on Pakistan FDI is also discussed in the ESCAP Statistical Yearbook (United Nations Economic and Social Council for Asia and Pacific, 2014) ${ }^{5}$. Most of the studies on FDI in Pakistan so far use annual data, such as Malik and Malik (2013), Gudaro et al.

\footnotetext{
${ }^{4}$ The data series is obtained from systemicpeace.org.

${ }^{5}$ http://www.unescap.org/resources/statistical-yearbook-asia-and-pacific-2014.
} 
(2012), Danish and Akram (2014), Basnet and Pradhan (2014), and Raza et al. (2015). Our study investigates the relationship in a single country setting, and econometrically there is no scaling problem. Thus, we employ the log value of FDI inflow (FDI) as a dependent variable.

The descriptive statistics ${ }^{6}$ show that half of these data are negatively skewed; therefore, there is an $\mathrm{ARCH}$ (i.e. autoregressive conditional heteroskedasticity) effect present in these data and most are non-normally distributed. For our empirical institutional environment models, we have checked the stationarity of the selected variables by testing random walk using the augmented Dickey-Fuller (1979) test. The results indicate that most of the variables are stationary at first-difference but four of them are stationary or integrated of order zero (i.e. $I(0)$ ) at level, such as FDI (foreign direct investment), CL (civil liberties), POLIIV (Polity-IV) and LCOST (average labour cost). Hence, all variables have been synchronized based on respective model requirements ${ }^{7}$.

\subsection{Empirical modelling}

To evaluate the effect of institutional quality on FDI inflow in Pakistan, we adopt three steps. In the first step, we measure the relationship using the multivariate OLS model below.

$$
\begin{gathered}
F D I_{t}=\beta_{0}+\beta_{1}(S G O V)_{t-1}+\beta_{2}(S M O N)_{t-1}+\beta_{3}(R E G U L)_{t-1}+\beta_{4}(P R O R)_{t-1}+ \\
\beta_{5}(F T R A D)_{t-1}+\beta_{6}(P R)_{t-1}+\beta_{7}(C L)_{t-1}+\beta_{8}(P O L I I V)_{t-1}+\beta_{9}(L C O S T)_{t-1}+\varepsilon_{2 t} \text { (i) }
\end{gathered}
$$

where, FDI is the $\log$ of FDI; $\beta_{0}$ is the constant; $\beta_{1}$ to $\beta_{9}$ are the coefficients of each institutional and control variable; and $\varepsilon_{2 t}$ is the error term. It is well held that an FDI decision may be made based on historical data and hence all the independent variables that are supposed to have an effect on FDI inflow would manifest their effect from the next period onward (see Anyanwu, 2011). We, therefore, apply the Schwarz Information Criterion (SIC) to select the optimum lag length for our model. As a consequence, all the independent variables are lagged by one period. Further, lagging

\footnotetext{
${ }^{6}$ The descriptive statistics are not reported but are available on request.

${ }^{7}$ All variables are converted to stationary to perform the granger causality test and also to run the VAR model. Stationary data has also been used for the regression.
} 
the explanatory variables helps to minimize endogeneity problems, as suggested by Neumayer and Spess (2005).

In the second step, we estimate three additional models using Equation (i) - to examine the impacts of pre-and post-liberalization (and structural break), and the types of ruling government in Pakistan. In order to examine the influence of government type, we use a dummy variable, 1 , for military-led government, and 0 for democratic government. Pakistan has faced three successful and three unsuccessful military coups spanning almost thirty-five years (Hayat et al., 2016). Moreover, in 2013, for the first time since independence, control of government was peacefully transferred from one democratic government to another. Hence, we expect that this variable may give us further insight into the influence of institutional quality on FDI inflow. We have checked the correlation between this dummy and Polity-IV, which is $-11.20 \%$, and is not statistically significant. Thus, government types and Polity-IV do not present similar information in our model. Further, we apply the Unit Root Test with a Breakpoint (Perron, 1989) to take account of any possible structural break in FDI inflow in Pakistan. Perron (1989) points out that structural change and unit roots are closely related, so that conventional unit root tests may be biased toward a false unit root null when the data are trend stationary with a structural break. Hence, we use a general Dickey-Fuller based innovational outlier (IO) test to capture the break dynamics (Perron, 2006). For the IO model, we consider the following general null hypothesis:

$$
y_{t}=y_{t-1}+\alpha+\psi(L)\left(\theta D_{t}\left(T_{b}\right)+\gamma D U_{t}\left(T_{b}\right)+\epsilon_{t}\right)
$$

where $\epsilon_{t}$ are i.i.d. innovations, and $\psi(L)$ is a lag polynomial representing the dynamic of the stationary and invertible ARMA (Autoregressive moving average) error process. Note that the break variable (i.e. $D U_{t}\left(T_{b}\right)$ ) enters in the model with the same dynamics as the $\epsilon_{t}$ innovation. $T_{b}$ is the break date. For alternative hypothesis, we assume a trend stationary model with breaks in the intercept and trend:

$$
y_{t}=\mu+\alpha t+\psi(L)\left(\theta D U_{t}\left(T_{b}\right)+\gamma D T_{t}\left(T_{b}\right)+\epsilon_{t}\right)
$$


We apply a general Dickey-Fuller test which nests the two hypotheses with an assumption of nontrending data and intercept break as suggested in Perron (1989), and Vogelsang and Perron (1998):

$$
\left.y_{t}=\mu+\theta D U_{t}\left(T_{b}\right)+\omega D_{t}\left(T_{b}\right)+\alpha y_{t-1}+\sum_{i=1}^{k} c_{i} \Delta y_{t-i}+u_{t}\right)
$$

Setting the trend and trend break coefficient $\beta$ and $\gamma$ to zero yields a test of a random walk against a stationary model with an intercept break. This is sufficient assumption for FDI as it implies, there are random shocks with permanent effects amounting to the random walk component (i.e. $\log$ FDI). In this equation (iv), lag length is selected based on Schwarz Information Criterion and break date selection assumption is to minimize the Dickey-Fuller $t$-statistics.

In the final step, we apply the Granger causality test (Granger, 1969) and the vector autoregression (VAR) model of Sim (1980) to check the robustness of the association between FDI inflow and institutional quality. By using these methods, we gain a better understanding of the bidirectional interrelationship between the variables of our study. For the pairwise Granger causality, we consider two series $a_{t}$ and $b_{f}$. Our estimate equations are, thus, the following.

$$
\begin{aligned}
& \Delta a_{t}=\rho_{0}+\sum_{i=1}^{n} \rho_{1 i} \Delta a_{t-1}+\sum_{i=1}^{m} \rho_{2 i} \Delta b_{t-1}+\epsilon_{1 t} ; \text { and } \\
& \Delta b_{t}=\delta_{0}+\sum_{i=1}^{n} \delta_{1 i} \Delta b_{t-1}+\sum_{i=1}^{m} \delta_{2 i} \Delta a_{t-1}+\epsilon_{1 t}
\end{aligned}
$$

We use an F-test for the joint significance of the coefficients, assuming a null hypothesis that $a_{t}$ does not Granger cause $b_{t}$ and vice versa. In the null hypothesis, we test that the lagged endogenous variables of interest (i.e. FDI inflow and institutional quality) do not Granger cause the dependent variable of interest (again, either FDI inflow or institutional quality variables). A rejection of the null hypothesis shows the presence of Granger causality.

The VAR model, on the other hand, allows us to analyse the contemporaneous and intertemporal linear relationship between the variables. The VAR model used in this study can be expressed as follows.

$$
X_{t}=c+\sum_{j=1}^{k} B_{1 j} X_{t-j}+\varphi_{t}
$$


Where, $X_{t}$ is a vector that represents endogenous variables - FDI, size of government, sound money, regulations, property right, freedom of trade, political right, civil liberties, polity-IV and labour cost; $c$ is the vector of intercept; $B$ is a ten $\times$ ten coefficient matrix (for FDI, each institutional quality variables and control variable); and $\varphi_{t}$ labels the vector of residuals. The number of lags (i.e. $k$ ) is estimated based on the Akaike information criterion and the Schwarz information criterion. When the two criteria indicate different lag lengths, we choose the lesser lag length for parsimony. As discussed in the previous section, the augmented Dickey-Fuller (1979) test is used to check the non-stationarity of the variables. To clarify the VAR results, we use impulse response function, which is sensitive to the ordering of the endogenous variables. Therefore, in determining the ordering, we rely on the prior evidence, following Goyenko and Ukhov (2009). We order our variables for each model as follows: institutional quality variables, control variables, and then the FDI. We put FDI at the end of the VAR ordering in our estimation to gain stronger statistical power (Goyenko and Ukhov, 2009).

\section{Empirical findings}

\subsection{Correlation analysis}

The correlation matrix is presented in Table 4, providing an approximation of the relationship between FDI with other variables in the model. In general, we would expect that all five indicators of the institutional environment are positively related to FDI inflows because stronger institutions attract foreign investors (Pajunen, 2008).

Insert Table 4 here.

The results indicate that five variables, including the control variables (LCOST), are significantly associated with FDI inflow in Pakistan. Among them, the highest correlation of FDI is found to be with freedom to trade internationally (FTRAD), while the lowest is with regulations (REGUL). These indicate that market liberalization is likely to enhance Pakistan's access to FDI. However, 
credit, labour or business regulations are not greatly influential. Further, access to sound money $(\mathrm{SMON})$ and political rights (PR) are found to be negatively related to FDI. Similarly, the freedom to trade internationally and labour cost are negatively related with most of the institutional quality variables. Political rights and civil liberties are not very relevant in Pakistan for institutional quality. Surprisingly, though, regulations are highly related to the size of government and access to sound money. This is to be expected, since a stronger government may impose and maintain better governance in an emerging market such as Pakistan's. Equally, with strong regulations, citizens may have better access to sound money.

\subsection{Multi-variate analysis results}

We first investigate whether there is a significant association between institutional quality and FDI inflow in Pakistan using multivariate OLS regression as in Equation (i). The Schwarz information criterion is used to select the number of lags in our multivariate OLS regression. The residualbased integration is also tested to check if the model is spurious. Results are reported in Table 5 .

\section{Insert Table 5 here.}

As shown in Table 5, for the overall sample, size of government, regulations, freedom to trade internationally, political rights, democracy and the control variable have a significant influence on FDI decisions of the MNEs. These findings are consistent with those in Table 4, with some exceptions. For instance, SGOV, FTRAD, and POLIIV have positive impacts on the next year's FDI inflow. However, unlike correlation, the current condition of credit market, labour market and business regulations have a substantial (which is 0.8591 and significant at $1 \%$ level) and affirmative impact on the FDI decision. Similarly, the average labour cost is negatively related to the following year's FDI inflow (which is -3.8340 and significant at the $10 \%$ level). Political rights also become statistically significant. But, surprisingly, the current year index of access to sound money is negatively related to FDI inflow in the subsequent year, although insignificantly.

The summary statistics and residual based diagnostic tests in column two of Table 5 represent the 
overall fitness of our OLS estimation. The $R^{2}$ and adjusted $R^{2}$ values clearly indicate higher explanatory power of independent variables. The significance of F-statistics at the $1 \%$ level shows the aggregate fitness of our multivariate OLS model. The ADF test and Breusch-Godfrey LM test confirm that there are no unit roots in the residuals and there is no serial correlation in our model. Similarly, the heteroskedasticity test using ARCH-LM confirms that there is no ARCH effect in the residuals. Finally, the Jarque-Bera (1987) test indicates that we cannot reject the null hypothesis - the residual is normally distributed.

\subsection{Structural break and market liberalization effect}

It is often argued that market liberalization improves institutional quality (Bhattacharyya, 2012) and increases FDI inflows in a country (Kim et al., 2013). In line with this argument, we examine the dynamic association between institutional quality and FDI inflow during pre- and postliberalization episodes in Pakistan. It is expected that in a post-liberalization period, institutions should play a more positive role in FDI inflow. In addition, due to change in dynamic interrelationship, one could expect a structural shift in FDI inflow around the liberalization date. Hence, we investigate this possible shift. We apply the general Dickey-Fuller based innovational outlier (IO) test to capture the break dynamics (see, Perron, 2006) using Equations (ii) to (iv). Figure 1 displays the test statistics graph (a) and AR specific graph (b).

Insert Figure 1.

Our unit root based structural test shows that there is a structural break in FDI inflow in Pakistan, which occurs in 1991. This indicates that the dynamics of FDI inflow in Pakistan are statistically different between pre-and-post 1991. Interestingly, but not unexpectedly, the structural break date of FDI inflow also coincides with the market liberalization date in Pakistan (see Bekaert et al., 2003 for market liberalization date in emerging markets), which indicates that liberalization has transformed the interrelationship between the factors under examination. In early 1991, the 
government announced a far-reaching package of economic reforms intended to stimulate economic growth through increased private-sector investment and productivity (Looney, 1997). In terms of implementation, the reforms centred upon disinvestment of public enterprise, deregulation and denationalization. It could be argued that, despite the difficult domestic economic conditions and several changes in government since 1991, Pakistan authorities have shown remarkable continuity in their approach to economic policy (Looney, 1997) and attracted a relatively higher amount of FDI (Shah et al., 2016).

To examine the dynamic relationships of FDI inflow with institutional quality before and after the structural break (identical to the pre- and-post liberalization period), we estimate the models using Equation (i) by dividing the sample into the 1972-1990 period and the 1991-2016 period. Columns four to seven in Table 4 present the results of the pre-and post- structural break on FDI inflow. The results indicate a significant structural shift in the relationship between institutional quality variables and FDI. Specifically, during the pre-liberalization episode the size of government had a negative impact on FDI; however, the relationship becomes positive in the post-liberalization period. Similarly, civil authorities is insignificant in the pre-break period, but becomes significant at the $1 \%$ level during the post-break episode. Furthermore, legal structure and security of property rights (PROR) and average labour cost (LCOST) are found to be significant only during the poststructural break period. These results are well in line with the theoretical argument for FDI as foreign investors are always looking for cheap labour and an established legal system in a host country. Most notably, the variables representing regulations play an important role as a determinant of the FDI decision taken by MNEs during both periods.

\subsection{Military versus conventional government in Pakistan}

We re-estimate the regression model using Equation (i) with an additional variable representing the type of government (GOVS) - military vs. conventional government system. We take it as a control variable for the political factor or political stability; because, in Pakistan, there were two 
prominent episodes during our study period, when government was led by the military (i.e. from 1977-1984 and 2000-2007). This variable is considered to be one of the important determinants of FDI inflow by many earlier studies, such as those conducted by Lawton et al. (2013), Asiedu (2013), Daude and Stein (2007), Khanna and Rivkin (2001), and North (1990). Moreover, we have tested the correlation between GOVS and POLIIV. The test result confirms that the two variables do not represent similar information. Hence, we incorporate this variable into Equation (i) as follows:

$$
\begin{gathered}
\text { FDI } \left._{t}=\beta_{0}+\beta_{i} \text { (Institutional quality variables }\right)_{t-1}+\beta_{9}(\text { Controls })_{t-1}+ \\
\beta_{9}(\text { Dummy for type of government, GOVS })_{t}+\varepsilon_{2 t}, \quad i=1,2, \ldots 8
\end{gathered}
$$

The model considers the possible influence of the current state of government, and hence no lag value of GOVS is included in the estimation. The final two columns of Table 5 exhibit the reestimated regression model using Equation (viii). The results demonstrate a similar relationship between FDI inflows and institutional quality variables to those estimated for the whole sample. It is worth noting that once we have incorporated the GOVS variable, average labour cost, i.e. LCOST, becomes statistically insignificant. Surprisingly, the type of government generates a positive effect, though at a small magnitude at 0.0350 . This indicates that a military government in power would enhance FDI inflows in Pakistan.

\subsection{Robustness tests}

In this section, we perform a variety of robustness checks for our main findings. We first assess the bi-directional causal associations between the variables using the Granger causality test (Granger, 1969). Table 6 presents the pairwise Granger causality between FDI inflows in Pakistan and its institutional quality as a host country. We use the Schwarz and Akaike information criterion for selecting the lag length for our models.

Insert Table 6 here. 
In Table 6, Panel A presents the results for the null hypothesis: the lagged endogenous variables of interest (i.e. institutional quality) does not Granger cause the dependent variable of interest (i.e. FDI inflow); and Panel B presents the results for bidirectional causality between them. The results indicate that some of the institutional quality variables significantly Granger cause the FDI inflows in Pakistan. In particular, the size of government, regulations, freedom to trade internationally, democracy and average labour cost are found significant at the 1 to $5 \%$ level. These are consistent with most of our findings in Tables 4 and 5. Taken together, we can conclude that institutional quality in Pakistan is an important determinant for MNEs when making investment decisions. The results further indicate strong bi-directional Granger causality from FDI inflows to regulations and labour cost, suggesting that MNEs may possibly influence the regulatory framework and also set up the average labour cost in Pakistan.

To gain further understanding of the dynamic relationship between the FDI decision and institutional quality of the host country within the VAR system, we estimate the impulse response functions (IRFs). As discussed in Section 4.3, to preserve strong statistical power as suggested in Goyenko and Ukhov (2009), we put our variables in the following order: institutional quality variables, control variables, and finally FDI. Figure 2 displays the accumulated responses of FDI inflows to one unit standard deviation innovation in institutional quality shocks, which is traced forward over a period of 10 years. Year 0 indicates the contemporaneous impact and Years 1-10 trace the effect from +1 to +10 years. The responses are measured using standard Cholesky decomposition of the VAR residuals. Bootstrap 95 percent confidence bands are provided to gauge the statistical significance of the responses.

Insert Figure 2 here.

The IRF results show that FDI inflows in Pakistan are positively influenced by the shocks from four institutional quality factors. Specifically, the impact of the regulatory framework, i.e. credit market, labour market and business, legal structure, security of property rights, and freedom to 
trade internationally of the host country, have a more pronounced, stronger and longer-lasting effect on FDI inflows. These four factors generate a contemporaneous impact and increase FDI to 0.5 standard deviation, excluding shocks of property right, which increase FDI inflows by up to 10 standard deviations. However, the size of government creates a negative impact in the short run (for the first 3 years), but increases the FDI by around 2 standard deviations in the long run (in ten years' time). On the other hand, FDI is negatively sensitive to such factors in the same way as civil liberties and average labour cost from year one. These factors reduce FDI inflows by 10 and 20 standard deviations in ten years' time, respectively. Further, the shocks from access to sound money, political rights and democracy affect the investment decisions of MNEs positively in the short-term (up to 3 to 4 periods) and then negatively in the long-term, starting from period four to five until the end of the observation periods. The shocks to political rights can reduce FDI inflows by 1.5 standard deviations, but the shocks to sound money and POLIIV (democracy) remain within 1 standard deviation.

As we have seen, most of these responses are expected, as they follow theoretical arguments and are well in line with our earlier findings, except for those responses to the shocks from civil rights and democracy, which are neither pronounced nor strong. The IRFs of these two variables, nevertheless, present an interesting characteristic of Pakistan. Together with Table 5, the results show that in the short-run the democratic government positively influences FDI inflows, but in the long-run it has a negative impact on the investment decisions of MNEs. This evidence suggests that democratic government may have been involved in large-scale corruption, abuse of the legal system, presenting a threat to civil rights, and patronizing terrorism and may have caused a loss of trust from international investors, as suggested in Shah et al. (2016), Hayat et al. (2016), and Tahir et al. (2015), hence contributing to the decreasing trend of FDI inflows to Pakistan in the longrun.

To observe the response of FDI inflows to a unit standard deviation shock from the military vs. 
conventional government (i.e. the type of the government in power, GOVS), we further run a VAR model. This would help us to gain a better understanding of the relationship between GOVS and FDI reported in Table 5; and the IRFs of FDI inflows to POLIIV (i.e. democracy) as reported in Figure 2. Figure 3 shows the accumulated responses.

Insert Figure 3 here.

Surprisingly, the impulse response is positive at the start but becomes flat after the third period. This indicates that with the military government in power, FDI inflows take a positive shift up to around 0.5 of a standard deviation in the short run. This supports our findings presented in the last column of Table 5. The response implies that when international investors lose their trust in the democratic government after a while, the military government could possibly show strong leadership, creating good economic prospects (see Hayat et al., 2016).

This result has further motivated us to explore the possible influence of the military government on institutional quality in Pakistan. We are incentivised to examine what happens to the institutional environment when a military government is in power by means of estimating the response of IRFs of institutional factors to the shocks to GOV. Table 7 summarizes the accumulated responses. Interestingly, the IRFs indicate that overall institutional quality improves after some time when a military government is in power. Further, our control variable, i.e. average labour cost, is also positively affected. Therefore, the findings lead us to conclude that the shortterm increase in FDI inflows during the term of a military government is probably due to the expectation of better institutional quality.

Insert Table 7 here.

\subsection{Comparative analysis for policy implication}

In the following analysis, we examine which factors, in particular, a government should emphasise when it seeks to boost its FDI and increase economic growth. To this end, we use an elasticity weight index (EWI), which allows us to compare all the factors on a homogenous basis. To 
construct the index, we estimate the elasticity following the procedure suggested by Hiller et al. (2011). The elasticity is calculated for each of the institutional and control variables used in various regression models. Elasticities are computed below:

$$
h_{e}=n_{e} \frac{\bar{g}_{e}}{n^{\prime} \bar{g}}
$$

where, $e$ represents each institutional and control variable; $n_{e}$ denotes the coefficient; $\bar{g}_{e}$ is its mean; and $n^{\prime} \bar{g}$ is the estimate of the expected value of the dependent variable based on the mean value of each regressor. Since the elasticities from the different models cannot be compared directly (Hiller et al., 2011), we determine the elasticity weight index (EWI) by measuring the respective power (weight) of each independent variable in various models. The index is computed below:

$$
E W I_{f}=\frac{\sum \frac{h_{e}}{\sum h}}{r}
$$

where, $h_{e}$ is the elasticity of each institutional and control variable; $\sum h$ is the sum of the elasticity for the coefficients on all the explanatory variables; and $r$ is the number of models where the variables have been used. We do not account for the sign of elasticity in estimation of the index as it indicates the direction of the relationship. By using this equation, we capture the weight of explanatory power of each institutional and control variable with respect to FDI inflows. Therefore, the higher the weight, the greater the contribution a factor will have in influencing FDI inflows in Pakistan. The results are reported in Table 8.

Insert Table 8 here.

The results clearly show that labour cost has the highest weight $\left(E W I_{L C O S T}=4.3321\right)$ and thus is the most sensitive driver of FDI inflows in Pakistan. Regulation, which comprises credit market, labour market and business regulations, appears to be the second most important driver of FDI $\left(E W I_{R E G U L}=2.8605\right)$. Other significant factors include political rights $\left(E W I_{P R}=1.2245\right)$, 
size of government $\left(E W I_{S G O V}=0.9681\right)$ and freedom to trade internationally $\left(E W I_{F T R A D}=\right.$ 0.9370). These results are significant as they provide important policy guidance to the Pakistan government.

\subsection{Discussions of the results}

Our results consistently show that general government consumption spending is positively associated with FDI inflows in Pakistan. In particular, this variable indicates the extent of government involvement in the economy. In effect, more government spending helps to build infrastructure, better corporate governance and a skilled workforce through enhanced education and training, which is expected to have a positive impact on FDI inflows. In this regard, Wheeler and Mody (1992) and Oates (1999) provide comprehensive evidence in respect of this relationship. Moreover, based on a survey of global executives, Tarzi (2005) argues that one of the most important host country location advantages that would attract FDI is the magnitude of government spending. Infrastructural development, in the form of the construction and maintenance of roads and bridges, electricity generation and transmission, information and communication development, as part of a wider government spending programme, can effectively help to attract foreign investment (see Tarzi, 2005).

Regulation of the credit market, labour market, and business in Pakistan are also found to be positive and significant at the various significance levels. Moreover, our elasticity analysis demonstrates that this factor should be ascribed the highest weight among all institutional variables in explaining the FDI decision-making of MNEs. This indicates that regulations are very important in exerting a positive impact on foreign and domestic investors (see, Asiedu, 2013; Daude and Stein, 2007; Wei, 2000; Gastanaga et al. 1998). We argue that effective regulatory regimes would lead to a more competitive output market and consequently an efficient allocation of goods and resources. Wei (2000) points out that poorly regulated institutions, or a complete lack of institutional governance, are considered to be a tax on foreign investors. Similarly, Gastanaga et al. 
(1998) report that corruption and bureaucratic delays, as well as poor enforcement of law and order in developing countries, significantly deter the inflow of much needed FDI to support economic growth. The rule of law, regulatory quality, the level of corruption, and the enforcement of government contracts in recipient countries are significant determinants of the FDI decision, as suggested in Asiedu (2013) and Daude and Stein (2007), among many others.

The third factor, which is found to be strongly positive in most of our regressions, is freedom to trade internationally. Moreover, the structural break in FDI inflows in Pakistan coincides with the market liberalisation date (see Figure 1). These results indicate that trade openness is an important determinant of FDI inflows, as less openness leads to less integration and higher transaction costs (see Villaverde and Maza, 2015; Asiedu, 2002). The evidence from Villaverde and Maza (2015) on the European regions and the evidence of Asiedu (2002) on Sub-Saharan African (SSA) and nonSSA countries, support the significant, positive role of trade openness in FDI inflows. In respect of other emerging and small markets, Goh et al. (2013) report a positive association between trade openness and FDI inflow for Malaysia; Musila and Yiheyis (2015) for Kenya; and Belloumi (2014) for Tunisia.

The final institutional variable, which has a positive role in attracting inward FDI in Pakistan, is POLIIV (i.e. democracy), but it has less power to influence the FDI decision of MNEs as reported in Table 8. However, in our robustness test, this factor negatively influences FDI inflows after three years. This may suggest that democracy helps to attract foreign investment but it does so for only two to three years. Increasing corruption, lack of good governance, lack of the rule of law, abuse of regulations, and bureaucratic and administrative barriers may have hindered FDI inflows after this period in Pakistan (see Shah et al., 2016, Hayat et al., 2016, and Tahir et al., 2015). A similar argument is also documented for other developing and developed countries in Asiedu (2013), Barthel et al. (2010), Daude and Stein (2007), Wei (2000), and Gastanaga et al. (1998).

In contrast to the effect of a democratic government, a military government shows a favourable 
influence on inward FDI in the long run (see Figure 3 and last column in Table 5). Moreover, institutional quality also improves during the reign of a military government (see Table 6). This implies that foreign investors prefer to make investments in Pakistan when the military are in power, which gives rise to better institutional qualities. Furthermore, army government as a form of autocracy may have been successful in fighting terrorism in Pakistan and that may have attracted FDI.

Chenoweth (2013) stated that democracy can cause a threat of terrorism in lower income countries and Pakistan has been a place of an acute terrorism threat in recent times (Ismail and Amjad, 2014). The authors reported that there has been a significant rise of terrorism in Pakistan since 1995 but that it started to slow down in 1999. The terrorism threat was at a minimum during the period from 1999 to 2008 and started to increase again after 2008. It is pertinent to mention that there was military government in Pakistan between 1999 and 2008, led by General Parvez Musharraf. This indicates that tougher actions by military government helped to reduce the terrorism threat, as stated by Ismail and Amjad (2014). Moreover, Raheem et al. (2014) argue that since the independence of Pakistan, government has been subjected to several military coups for more than three decades, and, as a result, the authors claim that economic performance and economic stability were far better during the time of military rule than under democratic government. In a recent study, Hayat et al. (2016) estimate that the average FDI during a period of democratic government is reduced by $0.19 \%$ more than the average FDI under military rule. They also claim that Pakistan consistently enjoyed an economic boom under military regimes. Similar findings are also reported in Gani and Al-Abri (2013) for Gulf Cooperation Council (GCC) countries.

Further, we find that political rights and average labour cost have negative impacts on inward FDI in Pakistan, and both have the significant power to influence the FDI decision by MNEs (see Table 8). In fact, the stability of the overall political environment is an important element for locational advantage, as argued by Dunning in his OLI paradigm. A stable political environment 
attracts FDI to the host country. Villaverde and Maza (2015), Naude and Krugell (2007) also point out that the political stability of a host country helps to attract FDI. However, an alternative view suggests that a weaker political environment can work as an opportunity for foreign investors. In this regard, foreign companies can influence a weaker political government to reap economic benefits such as tax avoidance and by expediting their own agenda through bribery. Frynas and Mellahi (2003) provide evidence that foreign firms benefit from their investments in Nigeria due to weak and fragile political systems. Bartels et al. (2014) point out that a poor and corrupt political environment can help attract foreign investment. The basic notion of these unconventional outcomes lies in the practice of corporate political activities. A weak political environment provides the opportunity for foreign firms to engage in local political activities and exploit the system to maximize the firms' benefit (Lawton et al., 2013). Therefore, the relationship between the local political environment and FDI inflows may well be negative in emerging countries. Our results confirm this fact, and are also in line with the findings of Büsse \& Hefeker (2007) and Bussmann (2010).

Finally, the negative impact of average labour cost is documented in Bellak et al. (2008), Johnson (2006), Bevan et al. (2004) and many others. Labour cost is frequently considered to be among the key economic variables in the discussion of the determinants of investment location decisions of firms (see Havlik, 2005). Our results in Table 8 further confirm this notion, and report that labour cost has the maximum power to influence the FDI decision by MNEs in Pakistan. This result is significant, as it indicates that Pakistan can attract foreign investment as a destination of cheap labour, while an increase in average labour cost would significantly reduce FDI inflows. Along this line of thought, Bellak et al. (2008) investigate the influence of labour costs on FDI inflows into central and eastern European countries and report that both higher unit labour costs and higher total labour costs negatively affect FDI.

\section{Conclusions and policy implications}


In this study, we examine how the host country's institutional factors affect FDI inflows into Pakistan. Most previous works on inward FDI in Pakistan focus on traditional economic factors: very few have examined institutional factors. In our study, we examine a broader spectrum of institutional factors and assess their impact on FDI inflows. We further evaluate the relative importance of institutional determinants by way of elasticity tests, which is novel in FDI determinant literature. We draw three conclusions.

First, a sound institutional environment attracts more FDIs into emerging markets such as Pakistan's. In particular, government expenditure and the tax rate, a stronger regulatory framework and the freedom to trade internationally, i.e. market liberalisation, have had a positive influence on FDI inflows in Pakistan. These results are consistent with the general prediction of institutional theory, that greater institutional quality enhances the locational advantage and hence attracts greater volumes of foreign investment (Pajunen, 2008). Second, democracy increases the inward FDI in the short-run; whereas a military government has a stronger influence on FDI in the longrun. Further, a stronger political environment has a negative effect on FDI inflows. This finding supports the expectation that stringent regulations and a stronger political environment reduce the opportunities for cross-border investors to exploit the system to enhance the profitability of their ventures.

The findings of this study have important implications for both academics and policy makers. From the academic perspective, this study is an extension of Dunning's OLI paradigm. We have discovered several important institutional factors, such as government size, legal environment, trade openness and form of government, that have significant impacts on inward FDI, and confirm that these institutional factors influence the locational advantage of a host country such as Pakistan. We therefore conclude that the locational advantage of a host country should be evaluated by an integrated system of institutional factors alongside the traditional factors such as GDP, market size, interest rate, and inflation. From the viewpoint of policy, our study has provided guidelines 
to policy makers so that they will be able to fashion their policies to attract investment from international investors. We conclude that Pakistan should provide enhanced government support in the public sector, improve regulatory quality and political stability, along with political and civil rights and trade openness, to attract more FDI. Our study demonstrates that the average labour cost and the quality of regulations are more important than other institutional factors in gaining an immediate momentum in FDI inflow. In the long run, Pakistan should focus on improving its overall institutional quality, which can be facilitated by market liberalisation, as demonstrated by our findings for the post-structural break period. Further, the positive influence of a military government on FDI in the long-run should alert Pakistan's politicians and policy makers to the systematic failure of democracy in providing a sound and stable business environment for the business community.

We finally submit that our study raises issues for future research. This study has used aggregate country-level data to analyse the effect of institutions on inward FDI in Pakistan. It would be of interest to examine the integrated institutional systems, as in our study, on FDI inflows in a multicountry setting. Another possibility would be to use micro-level institutional data to explore the potential impacts that they may have on FDI in emerging countries in general. The implications for countries in emerging markets having an imperfect institutional culture could usefully be investigated using our findings as a foundation. 


\section{References:}

Adam, A. and Filippaios, F. (2007). Foreign direct investment and civil liberties: A new perspective. European Journal of Political Economy, 23, 1038-1052

Ahlquist, J.S. (2006). Economic policy, institutions, and capital flow: portfolio and direct investment flows in developing countries. International Studies Quarterly, 50, 681-704.

Aizenman, J. and Noy, I. (2006). FDI and Trade - Two way Linkage. The Quarterly Review of Economics and Finance, Vol. 46(3), pp. 317 - 337.

Anyanwu, J. C. (2011). Determinants of Foreign Direct Investment Inflows to Africa, 1980-2007. Working Paper Series N 136, African Development Bank, Tunis, Tunisia.

Arregle, J-L., Miller, T.L., Hitt, M.A, and Beamish, P.W. (2016). How Does Regional Institutional Complexity Affect MNE Internationalisation? Journal of International Business Studies. May, pp. $1-26$.

Asiedu, E. (2002). On the Determinants of Foreign Direct Investment to Developing Countries: Is Africa Different? World Development, 30(1), 107-119.

Asiedu, E. (2006). Foreign direct investment in Africa: the role of natural resources, market size, government policy, institutions and political instability. The World Economy, 29(1), 63-77.

Asiedu, E. and Lien, D. (2011). Democracy, foreign direct investment and natural resources. Journal of International Economics, 84, 99-111.

Asiedu, E. (2013). Foreign Direct Investment, Natural Resources and Institutions. International Growth Centre, Working Paper.

Asimakopoulos, S. and Karavias, Y. (2016). The Impact of Government Size on Economic Growth: A Threshold Analysis. Economics Letters, Vol. 139, pp. 65 - 68.

Azam M., and Khattak N. (2009). Social and Political Factors Effects on Foreign Direct Investment in Pakistan. Gomal University Journal of Research, 25 (1),46-50

Bailey, N. (2018). Exploring the relationship between institutional factors and FDI attractiveness: A meta-analytic review. International Business Review, 27, 139-148.

Baldwin, R. (2016). The Great Convergence: Information Technology and the New Globalization. Harvard University Press.

Basnet, H. and Pradhan, G. (2014). Does the Inflow of FDI Stock Matter? Evidence from SAARC Countries. Economic Papers. 33(3), pp. 305 - 312.

Bartels, F.L., Napolitano, F. and Tissi, N.E. (2014). FDI in Sub-Saharan Africa: A longitudinal Perspective on Location-Specific Factors (2003 - 2010). International Business Review. 23, pp. $516-529$.

Barthel, F., Busse, M., Krever, R. and Neumayer, E. (2010). The Relationship Between Double Taxation Treaties and Foreign Direct Investment, M. Lang, P. Pistone, J. Schuch, C. Staringer, A. Stock 
and M. Zagler (eds.): Tax Treaties: Building Bridges between Law and Economics, Amsterdam: IBFD, pp.3-18.

Bekaert, G., Harvey, C.R. \& Lundblad, C.T. (2003). Equity market liberalization in emerging market. Journal of Financial Research. 26(3), pp. 275-299.

Bellak, C., Leibrecht, M. \& Aleksandra, R. (2008). Labour costs and FDI flows into Central and Eastern European Countries: A survey of the literature and empirical evidence. Structural Change and Economic Dynamics, 19, 17-37.

Belloumi, M. (2014). The relationship between trade, FDI and economic growth in Tunisia: An application of the autoregressive distributed lag model. Economic Systems, 38, 269-287.

Bevan, A., Estrin, S. and Meyer, K. (2004). Foreign investment location and institutional development in transition economies. International Business Review, 13(1), 43-64.

Bhattacharyya, S. (2012). Trade liberalization and institutional development. Journal of Policy Modelling, 34, 253-269.

Blanton, S.L. and Blanton, R.G. (2006). What attracts foreign investros? An examination of human rights and foreign direct investment. The Journal of Politics, 69(1), 143-155

Buchanan, B.G., Le, Q.V. and Rishi, M. (2012). Foreign direct investment and institutional quality: some empirical evidence. International Review of Financial Analysis, 21, 81-89.

Busse, M. (2004). Transnational Corporations and Repression of Political Rights and Civil Liberties: An Empirical Analysis, Kyklos 57 (1), 45-66.

Busse, M. and Hefeker, C. (2007). Political risk, institutions and foreign direct investment. European Journal of Political Economy, 23, 397-415.

Bussmann, M.(2010). Foreign Direct Investment and Militarized International Conflict, Journal of Peace Research, 47(2),143-153.

Büthe, T. \& Milner, H.V. (2008). The politics of foreign direct investment into developing countries: Increasing FDI through international trade agreements? American Journal of Political Science, 52(4), 741-762.

Caballero, R.J. and Hammour, M.L. (2001). Institutions, Restructuring and Macroeconomic Performance. Paper presented at XII World Congress of the International Economic Association, Buenos Aires, Argentina.

Chenoweth, E. (2013). Terrorism and Democracy. Annual Review of Political Science, Vol. 16, pp. $355-378$.

Choi, J.J., Lee, S.M. and Shoham, A. (2016). The effects of institutional distance on FDI inflow: General environment institution (GEI) versus minority investor protection institutions (MIP). International Business Review, 25, 114-123.

Danish, R. Q. and Akram, A. (2014). Determinants of FDI in Pakistan: An Empirical Analysis, Journal of International Business and Economics, 2(2), 61-70. 
Daude, C. and Stein, E. (2007). The quality of institutions and foreign direct investment. Economics \& Politics, 19(3), 317-344.

Delios, A. and Henisz, W. J. (2000). Japanese firms' investment strategies in emerging economies. Academy of Management Journal, 43(3), 305-323.

Dickey, D.A. and Fuller, W.A. (1979). Distribution of the estimators for autoregressive time series with a unit root. Journal of American Statistical Association, 74(366), 427-431.

Dunning, J.H. (1980). Toward an Eclectic Theory of International Production: Some Empirical Tests. Journal of International Business Studies. 11, pp. $9-31$.

Dunning, J.H. (2000). The Eclectic Paradigm as an Envelope for Economic and Business Theories of MNE Activity. International Business Review. 9, pp. 163 - 190.

Dunning, J.H. (2006). Towards a New Paradigm of Development: Implications for the Determinants of International Business. Transnational Corporation. 15(1), pp. 173 - 227.

Dutta, N. and Osei-Yeboah, K. (2013). A new dimension to the relationship between foreign direct investment and human capital: The role of political and civil rights. Journal of International Development, 25, 160-179.

Filippaios, F, Annan-Diab, F. and Hermidas, A. (2017). Civil and political liberties and FDI: An evaluation of emerging and developing economics. In: Ibeh K., Tolentino P., Janne O., Liu X. (ends) Growth Frontiers in International Business. The Academy of International Business. Palgrave MaCmillan, Cham

Fontagne, L. and Mayer, T. (2005). Determinants of location choices by multinational firms: a review of the current state of knowledge. Applied Economic Quarterly, 9-34, Supplement to issue 56.

Fraser Institute (2017). Economic freedom of the world. 2017 Annual Report.

Frynas, J.G. and Mellahi, K. (2003). Political Risks as Firm-specific (Dis)advantages: Evidence on Transnational Oil Firms in Nigeria. Thunderbird International Business Review. 45, pp. 541 - 565.

Gani, A. and Al-Abri, S. (2013). Indicators of business environment, institutional quality and foreign direct investment in gulf cooperation council (GCC) countries. International Review of Applied Economics 27, 515-530.

Garcia-Sanchez, I.M., Cuadrado-Ballesteros, B. and Frias-Aceituno, J. (2013). Determinants of Government Effectiveness. International Journal of Public Adminitration, Vol. 36, pp. 567 577.

Gastanaga, V., Nugent, J. B., and Pashamova, B. (1998). Host county reforms and FDI inflows: How much difference do they make? World Development, 26, 1299-1314.

Gevorkyan, A.V. and Canuto, O. (2016). Emerging Markets and The Post 2008 World. A.V. Gevorkyan, O. Canuto (eds.), Financial Deepening and Post-Crisis Development in Emerging Markets. 
Ghemawat, P. (2001). Distance still matters: The hard reality of global expansion. Harvard Business Review, September, 2001, pp. 137 - 147.

Globerman, S. and Shapiro, D. (2002). Global Foreign Direct Investment Flows: The Role of Governance Infrastructure, World Development Journal, 30(11), 1899-1919.

Globerman, S., and Shapiro, D. (2003). Governance Infrastructure and US Foreign Direct Investment. Journal of International Business Studies, 34(1), 19-39.

Goh, S.K., Wong, K.N. \& Tham, S.Y. (2013). Trade linkages of inward and outward FDI: Evidence from Malaysia. Economic Modelling, 35, 224-230.

Goyenko, R.Y. and Ukhov, A.D. (2009). Stock and bond market liquidity: a long-run empirical analysis. Journal of Financial and Quantitative Analysis, 44(1), 189-212.

Granger, C.W.J. (1969). Investigating causal relations by econometric models and cross-spectral methods. Econometrica, 37(3), 424-438.

Greider,W. (1998) OneWorld, Ready or Not: TheManic Logic of Global Capitalism (New York: Touchstone).

Gudaro, A. M., Chhapra, I. U., and Sheikh, S. A. (2012). Impact of foreign direct investment on economic growth: A case study of Pakistan. Journal of Management and Social Science. 8(2), pp. $22-30$.

Hakro, A.N. and Ghumro, I.A. (2011). Determinants of Foreign Direct Investments Flows to Pakistan. The Journal of Developing Areas. 44(2), pp. 217 - 242.

Haggard, S. (1990). Pathways from the Periphery: The Politics of Growth in the Newly Industrializing Countries (Ithaca, New York: Cornell University Press).

Haq, R. and Zia, U. (2009). Does Governance Contribute to Pro-poor Growth? Evidence from Pakistan, PIDE Working Papers No. 52, Islamabad, Institute of Development Economic.

Harms, P. and Ursprung, H. (2002). Do Civil and Political Repression Really Boost Foreign Direct Investment? Economic Inquiry, 40 (4), 651-663.

Havlik, P., 2005. Unit labour costs in the new EU member states. wiiw Statistical Reports Nr. 1, The Vienna Institute for International Economic Studies (wiiw), Vienna.

Hayat, M.N., Fatima, K., Mukhtar, U. \& Bano, S. (2016). Economic performance of Pakistan under democracy and military regimes. Journal of Economics, Business and Management, 4(12), 690694.

Henisz, W.J. (2000). The Institutional Environment for Multinational Investment. Journal of Law, Economics and Organization, Vol. 16(2), pp. $334-364$.

Hiller, D., Pindado, J., Queiroz, V.D. \& Torre, C.D.L. (2011). The impact of country-level corporate governance on research and development. Journal of International Business Studies, 42, 76-98. 
Holmes Jr., R.M., Miller, T., Hitt. M.A. and Salmador, M.P. (2013). The interrelationships among informal institutions, formal institutions and inward foreign direct investment. Journal of Management. 39(2), $531-566$.

Hoskisson, R., Eden, L., Lau, C. M. and Wright M. (2000). Strategy in Emerging Economies. Academy of Management Journal. 43(3), pp. 249 - 267.

Hunjra, A.I., Raza, S.A. and Asif, M.U. (2013). Impact of Macroeconomic Variables on Foreign Direct Investments in Pakistan. Bulletin of Business and Economics. 2(2), pp. 40 - 52.

Ismail, A. and Amjad, S. (2014). Determinants of Terrorism in Pakistan: An Empirical Investigation. Economic Modelling, Vol. 37, pp. 320 - 331.

Jarque, C.M. \& Bera, A.K. (1987). A test for normality of observations and regression residuals. International Statistics Review, 55, 163-172.

Jakobsen, J. and de Soysa, I. (2006). Do Foreign Investors Punish Democracy? Theory and Empirics, 1948-2001, Kyklos, 59(3)

Jensen, N. (2003). Democratic Governance and Multinational Corporations: Political Regimes and Inflows of Foreign Direct Investment. International Organization, 57(3).

Johnson, A. (2006). FDI inflow to the transition economics in Eastern Europe: magnitude and determinants. CESIS Working Paper No. 59

Kang, Y. and Jiang, F. (2012). FDI location choice of Chinese multinationals in East and Southeast Asia: Traditional economic factors and institutional perspective, Journal of World Business. Vol. 47, pp. 45-53.

Khan, A. H. (1997). FDI in Pakistan: Policies and Trends. The Pakistan Development Review, 36(4), pp. 959-85.

Khan, M.A. (2011). Foreign Direct Investment in Pakistan: The Role of International Political Relations. TMD Working Paper Series No. 039, University of Oxford.

Khanna, T. and Palepu, K. (2005). Spotting Institutional Voids in Emerging Markets. Harvard Business School Background Note 106-014, August, pp. 1 - 11.

Khanna, T. and Rivkin, J.W. (2001). Estimating the Performance Effects of Business Groups in Emerging Markets. Strategic Management Journal. 22(1), pp. 45 - 74.

Kim, D.H., Lin, S.C. \& Suen, Y.B. (2013). Investment, trade openness and foreign direct investment: Social capability matters. International Review of Economics and Finance, 26, 56-69.

Kostova, T. and Zaheer, S. (1999). Organisational Legitimacy under Conditions of Complexity: The Case of Multinational Enterprise. The Academy of Management Review, Vol. 24 (1), pp. 64 -81 .

Lawton, T., McGuire, S. and Rajwani, T. (2013). Corporate Political Activity: A Literature Review and Research Agenda. International Journal of Management Reviews. 15, pp. 86 - 105. 
Li, Quan and Resnick, A. (2003). Reversal of fortunes: Democratic Institutions and Foreign Direct Investment Inflows to Developing Countries. International Organization, 57(1),

Looney, R.E. (1997). The Pakistani economy: economic growth and structural reform. $1^{\text {st }}$ Edition, Library of Congress.

Malik, S. and Malik, Q. A. (2013). Empirical Analysis of Macroeconomic Indicators as Determinants of Foreign Direct Investment in Pakistan, Journal of Business and Management, $7(2), 77-82$.

Medvedev, D. (2012). Beyond trade: The impact of preferential trade agreements on FDI inflows. World Development, 40(1), 49-61.

MengYun, W., Imran, M., Zakaria, M., Linrong, Z., Farooq, M.U. and Muhammad, S.K. (2018). Impact of Terrorism and Political Instability on Equity Premium: Evidence from Pakistan. Physica A, Vol. 492, pp. $1753-1762$.

Mhlanga, N., Blalock, G. and Christy, R. (2010). Understanding Foreign Direct Investment In The Southern African Development Community: An Analysis Based on Project-Level Data, Agricultural Economics, 41(3-4), 337-347.

Musila, J.W. \& Yiheyis, Z. (2015). The impact of trade openness on growth: The case of Kenya. Journal of Policy Modelling, 37, 342-354.

Naude, W.A. and Krugell, W.F. (2007). Investigating Geography and Institutions as Determinants of Foreign Direct Investment in Africa Using Panel Data. Applied Economics. 39(10 - 12), pp. $1223-1233$.

Neumayer, E. and Spess, L. (2005). Do Bilateral Investment Traties Increase Foreign Direct Investment to Developing Countries? World Development. 33(10), pp. 1567 - 1585.

Newton, K. (1982). Is Small Really So Beautiful? Is Big Really so Ugly? Size, Effectiveness and Democracy in Local Government. Political Studies, Vol. 30 (2), pp. 190 - 206.

North, D. C. (1990). Institutions, institutional change and economic performance. New York: Cambridge University Press.

North, D.C. (1998). Economic Performance Through Time. In M.C. Brinton, \& V. Nee (Eds.), The new institutionalism in sociology (pp. 247 - 257). New York: Russell Sage Foundation.

Oates, W. (1999). An Essay of Fiscal Federalism. Journal of Economic Literature. 37(3), pp. 1120 -1149 .

Okada, K. (2013). The interaction effects of financial openness and institutions on international capital flows. Journal of Macroeconomics, 35, 131-143.

Olson, M. (1991). Autocracy, Democracy and Prosperity. In Strategy and Choice, Edited by Richard J. Zeckhauser, pp. 131 - 157, Cambridge, Mass: MIT Press.

Oxelheim, L. and Ghauri, P. (2008). EU - China and non-transparent race for inward FDI. Journal of Asian Economics. 19, 358 - 370. 
Pajunen, K. (2008). Institutions and Inflows of Foreign Direct Investment: A Fuzzy-set Analysis. Journal of International Business Studies, 39(4), pp. 652 - 669.

Perron, P. (1989). The Great Crash, the Oil Price Shock, and the Unit Root Hypothesis. Econometrica, 57, 1361-1401.

Perron, P. (2006). "Dealing with Structural Breaks," in Palgrave Handbook of Econometrics, Vol. 1: Econometric Theory, K. Patterson and T. C. Mills (eds.), Palgrave Macmillan, 278-352.

Raheem, A.R., Parmar, V., Ahmad, N. \& Ahmed, A.M. (2014). Economic and social progress under civilian and military setups in Pakistan. Developing Country Studies, 4(16), 12-18

Rammal, H.G. and Zurbruegg, R. (2006). The impact of regulatory quality on intra-foreign direct investment flows in the ASEAN markets. International Business Review, 15, 401-414.

Raza, S.A., Jawaid, S.T., Afshan, S. and Karim, M.Z. A. (2015). Is stock market sensitive to foreign capital inflows and economic growth?: Evidence from Pakistan", Journal of Chinese Economic and Foreign Trade Studies, 8(3),142-164.

Reinhardt, D., Ricci, L.A. and Tressel, T. (2013). International capital flows and development: financial openness matters. Journal of International Economics, 91, 235-251.

Rottig, D. (2016). Institutions and emerging markets: effects and implications for multinational corporations. International Journal of Emerging Markets, Vol. 11(1), pp. 2 - 17.

Scott, W.R. (1995). Institutions and Organisations: Ideas, Interest, and Identities. Fourth Edition, London: Sage Publications.

Scott, W.R. (2014). Institutions and Organisations: Ideas, Interests and Identities, $4^{\text {th }}$ Edition, SAGE Publications, Thousand Oaks, CA.

Sethi, D., Guisinger, S.E., Phelan, S.E. and Berg, D.M. (2003). Trends in Foreign Direct Investment Flows: A Theoretical and Empirical Analysis. Journal of International Business Studies. 34(4), pp. 315 - 326.

Shah, S.H., Ahmed, M.H. and Ahmed, Q.M. (2016). The nexus between sectoral FDI and institutional quality: empirical evidence from Pakistan. Applied Economics, 48(17), 1591-1601.

Sims, C.A. (1980). Macroeconomics and reality. Econometrica, 48, 1-48.

Sobel, A. C. (2002). State Institutions, Risk and Lending in Global Capital Markets. International Business Review. 11(6), pp. 725 - 752.

Tahir, M., Khan, I. and Shah, A.M. (2015). Foreign Remittance, Foreign Direct Investment, Foreign Imports and Economic Growth in Pakistan: A Time Series Analysis. Arab Economics and Business Journal. 10, pp. $82-89$.

Tanaka, H. and Iwaisako, T. (2014). Intellectual property rights and foreign direct investment: A welfare analysis. European Economic Review, 67, 107-124. 
Tarzi, S. (2005). Foreign Direct Investment Flows into Developing Countries: Impact of Location and Government Policy. The Journal of Social, Political and Economic Studies. 30(4), pp. 497 515.

Trevino, L.J., Thomas, D.E. and Cullen, J. (2008). The Three Pillars of Institutional Theory and FDI in Latin America: An Institutionalisation Process. International Business Review. 17, pp. 118 $-133$.

Villaverde, J. and Maza, A. (2015). The Determinants of Inward Foreign Direct Investment: Evidence from the European Regions. International Business Review. 24, pp. 209 - 223.

Vogelsang, T. J. \& Pierre, P. (1998). Additional Test for Unit Root Allowing for a Break in the Trend Function at an Unknown Time. International Economic Review, 39, 1073-1100.

Wei, S. (2000). How taxing is corruption on international investors? Review of Economics and Statistics, 82(1), 1-11.

Wheeler, D., and A. Mody. (1992). International Investment Location Decisions: The Case of U.S. Firms, Journal of International Economics, 33, 57-76.

Xiao, S. S. and Park, B.I. (2018). Bring institutions into FDI spillover research: exploring the impact of ownership restructuring and institutional development in emerging economies. International Business Review, 27, 289-308.

Yuan, Y., Chen, Y. and Wang, L. (2010). Size of government and FDI: an empirical analysis based on the panel data of 81 countries. Journal of Technology Management in China. Vol. 5(2), pp. 176 -184 . 